\title{
Validation of Satellite Daily Rainfall Estimates Over Indonesia
}

\author{
Fatkhuroyan *, Trinah Wati, Alfan Sukmana, Roni Kurniawan \\ Agency for Meteorology, Climatology and Geophysics of Indonesia, Jl. Angkasa 1 No.2 \\ Kemayoran, Jakarta 10720, Indonesia \\ *) Corresponding Author (e-mail: fatkhuroyan@bmkg.go.id)
}

Received: 25 June 2018 / Accepted: 23 August 2018 / Published: 26 November 2018

\begin{abstract}
Rainfall is the most important factor in the Earth's water and energy cycles. The aim of this research is to evaluate the accuracy of Global Satellite Mapping of Rainfall (GSMaP) data by referencing daily rain-gauged rainfall measurements across the Indonesian Maritime Continent. We compare the daily rainfall data from GSMaP Moving Kalman Filter (MVK) to readings from 152 rain-gauge observation stations across Indonesia from March 2014 to December 2017. The results show that the correlation coefficient (CC) provides better validation in the rainy season while root mean square error (RMSE) is more accurate in the dry season. The highest proportion correct (PC) value is obtained for Bali-NTT, while the highest probability of detection (POD) and false alarm ratio (FAR) values are obtained for Kalimantan. GSMaP-MVK data is over-estimated compared to observations in Indonesia, with the mean accuracy for daily rainfall estimation being $85.47 \%$ in $2014,85.74 \%$ in $2015,82.73$ in 2016 , and $82.59 \%$ in 2017.
\end{abstract}

Keywords: GSMaP, rainfall, rain-gauge.

Abstrak. Curah hujan adalah faktor terpenting dari siklus air dan energi bumi. Tujuan dari penelitian ini adalah untuk mengevaluasi akurasi dari GSMaP (Global Satellite Mapping of Rainfall) dengan hasil pengukuran rain-gauged curah hujan harian di seluruh Benua Maritim Indonesia. Curah hujan harian GSMaP-MVK (Moving Kalman Filter) dibandingkan dengan 152 stasiun pengukur hujan (rain-gauge) selama periode bulan Maret 2014 - Desember 2017. Hasil penelitian menunjukkan bahwa nilai correlation coefficients (CC) lebih baik di musim hujan dan memiliki nilai RMSE terbaik di musim kemarau. Selain itu, nilai tertinggi Proportion Correct (PC) ada di Bali-NTT, nilai Probability of Detection (POD) tertinggi di Kalimantan dan nilai False alarm ratio (FAR) terbaik juga di Kalimantan. Akumulasi hujan GSMaP-MVK over-estimasi terhadap hasil pengamatan di Indonesia dengan akurasi rata-rata untuk prakiraan curah hujan harian adalah $85,47 \%$ pada tahun $2014,85,74 \%$ pada tahun 2015, 82,73 pada tahun 2016 dan 82,59\% pada tahun 2017.

Kata kunci: GSMaP, curah hujan, rain-gauge.

\section{Introduction}

Precipitation plays a vital role in the Earth's water and energy cycles and is also an important input for climate and hydrological models (Gottschalck et al., 2005; Kidd et al., 2011). Moreover, accurate rainfall estimation is crucial for monitoring hydro-climatologic variations. Flood and drought can be understood from rainfall analysis in order to protect the environment and enhance population security. Generally, rainfall datasets obtained from groundbased rain-gauge observations have been used to provide direct physical measurement of rainfall. However, rainfall monitoring at ground stations is often too sparse to provide the coverage needed for accurate patterns to be developed, especially in terms of spatial variability (Vernimmen et al., 2012). Few meteorological stations are available in remote areas and those that are present are not well distributed, due to difficulties of access for maintenance and installation. This lack of spatial coverage is a challenge for successful gauge-based rainfall measurement (Buarque et al., 2011; Chen et al., 2013) 


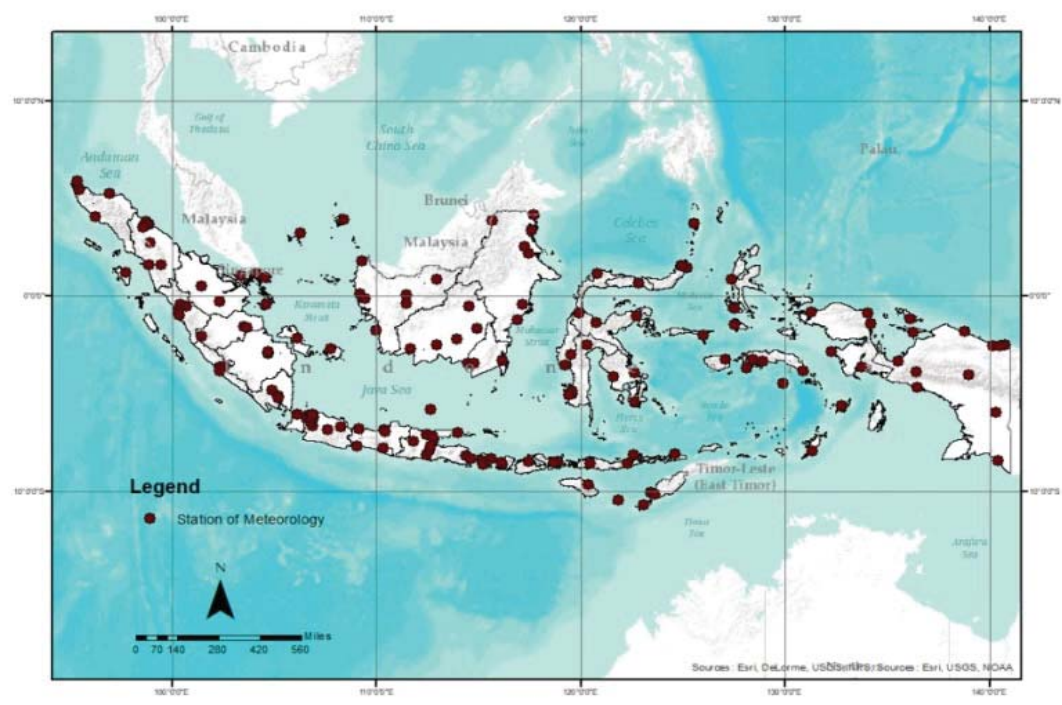

Figure 1. Rain-gauge network.

Over recent decades, numerous satellite rainfall estimates have been developed to improve understanding of the global water cycle and its effects on atmospheric circulation (Huffman et al., 2007; Aonashi et al., 2009; Kidd et al., 2009; Joyce et al., 2011). However, this data still involves uncertainties such as inhomogeneous patterns over diverse regions resulting from the indirect nature of satellite measurements, and influenced by inaccuracies in cloud top reflectance, thermal radiance, and infrequent satellite overpasses (AghaKouchak et al., 2009). The validation of rainfall estimates from satellite data is essential for assessing the accuracy of estimation algorithms and for providing feedback to algorithm developers to improve their methods. A number of studies have evaluated satellite-derived rainfall information for areas of interest by comparing it to rain-gauge rainfall data (Dinku et al., 2010; Sapiano, 2010; Scheel et al., 2011; Setiawati 2016; Giarno et al., 2018).

Efforts to improve retrieval algorithms and estimation techniques have resulted in the release of new products including Global Satellite Mapping of Rainfall (GSMaP), which is a set of new high-resolution rainfall estimates based on blending passive microwave (PMW) and infrared (IR) datasets (Ushio et al. 2009). Many evaluations and validations of GSMaP have been carried out in recent years. Kubota et al. (2007) assessed the accuracy of GSMaPMWR (microwave radiometer), reporting that the CC of GSMaP is high over the ocean but relatively low over the land surface. It is also higher in summer than in winter. GSMaP-MWR provides precipitation estimates derived from MW radiometer data using a GSMaP retrieval algorithm. Kubota et al. (2009) also evaluated GSMaP at 3-hourly and $0.25^{\circ}$ intervals across Japan by comparing GSMaP with a gaugecalibrated ground radar dataset. Promasakha et al. (2013) used daily GSMaP products for the period 2000-2010 for validation of raingauge station data in Thailand and concluded that GSMaP-MVK under-estimated over the area. GSMaP-MVK also showed that statistical verification of POD and TS is accurate in the rainy season but quite weak in the summer season. GSMaP-MVK provides precipitation estimates derived from temporal interpolation of the MW radiometer product using morphed technique and a Kalman filter for geostationary IR data. 
Table 1. List of statistical metrics used in the statistical evaluation.

\begin{tabular}{|l|c|c|}
\hline \multicolumn{1}{|c|}{ Statistical metric } & Equation & Perfect value \\
\hline Correlation coefficient (CC) & $C C=\frac{\frac{1}{N} \sum_{n=1}^{N}\left(f_{n}-\bar{f}\right)\left(r_{n}-\bar{r}\right)}{\sigma_{f} \sigma_{n}}$ & \\
\hline Mean error (ME) & $M E=\frac{1}{N} \sum_{n=1}^{N}\left(f_{n}-r_{n}\right)$ & 0 \\
\hline Mean absolute error (MAE) & $M A E=\frac{1}{N} \sum_{n=1}^{N}\left|f_{n}-r_{n}\right|$ & 0 \\
\hline Root mean square error (RMSE) & $R M S E=\sqrt{\frac{1}{N} \sum_{n=1}^{N}\left(f_{n}-r_{n}\right)}$ & \\
\hline
\end{tabular}

Notes: $n=$ number of samples; $f_{n}=a$ test field of $f$ representing a satellite rainfall estimate; $r_{n}=$ a reference field $r$ standing for rainfall gauge values.

Table 2. Contingencies for comparing GSMaP-MVK v.7 rainfall estimates and rain-gauge measurements.

\begin{tabular}{lccc}
\hline & Gauge $\geq \mathbf{1 ~ \mathbf { ~ m }}$ & Gauge $\leq \mathbf{1} \mathbf{~ m m}$ & Marginal total \\
\hline Satellite $\geq 1 \mathrm{~mm}$ & $\mathrm{a}$ & $\mathrm{b}$ & $\mathrm{a}+\mathrm{b}$ \\
Satellite $\leq 1 \mathrm{~mm}$ & $\mathrm{c}$ & $\mathrm{d}$ & $\mathrm{c}+\mathrm{d}$ \\
Marginal total & $\mathrm{a}+\mathrm{c}$ & $\mathrm{b}+\mathrm{d}$ & $\mathrm{a}+\mathrm{b}+\mathrm{c}+\mathrm{d}=\mathrm{n}$ \\
\hline
\end{tabular}

Table 3. Statistical values for 2014

\begin{tabular}{lcccc}
\hline \multicolumn{1}{c}{ Average values 2014 } & CC & RMSE & ME & MAE \\
\hline Sumatra & 0.47 & 16.93 & 0.71 & 7.66 \\
Java & 0.42 & 14.09 & 0.38 & 5.58 \\
Kalimantan & 0.51 & 15.20 & 0.37 & 7.05 \\
Sulawesi & 0.49 & 12.99 & -0.83 & 5.33 \\
Bali-NTT & 0.35 & 8.83 & 0.45 & 2.69 \\
Molucca-Papua & 0.48 & 15.80 & -0.76 & 6.87 \\
\hline
\end{tabular}

Table 4. Categorical values for 2014

\begin{tabular}{lcccccc}
\hline \multicolumn{1}{c}{ Average values 2014 } & PC & POD & FAR & CSI & ETS & FBI \\
\hline Sumatra & 0.73 & 0.79 & 0.37 & 0.53 & 0.30 & 1.29 \\
Java & 0.79 & 0.70 & 0.42 & 0.47 & 0.32 & 1.22 \\
Kalimantan & 0.76 & 0.81 & 0.32 & 0.58 & 0.35 & 1.20 \\
Sulawesi & 0.78 & 0.71 & 0.34 & 0.51 & 0.34 & 1.13 \\
Bali-NTT & 0.87 & 0.58 & 0.39 & 0.42 & 0.34 & 1.08 \\
Molucca-Papua & 0.73 & 0.69 & 0.35 & 0.50 & 0.26 & 0.98 \\
\hline
\end{tabular}

This study aims to evaluate the use of GSMaP rainfall estimates over Indonesia by using gauge-based rainfall analysis and exploring the error characteristics of GSMaP over the region for various underlying surface types and complex topography. The performance of GSMaP was investigated in this study as an alternative source of rainfall data which could be used to overcome the limitations of station coverage in Indonesia. 
Table 5. Statistical values for 2015

\begin{tabular}{lcccc}
\hline \multicolumn{1}{c}{ Average values 2015 } & CC & RMSE & ME & MAE \\
\hline Sumatra & 0.45 & 15.67 & 0.56 & 6.66 \\
Java & 0.47 & 15.83 & 1.20 & 5.71 \\
Kalimantan & 0.51 & 14.99 & -0.34 & 6.61 \\
Sulawesi & 0.51 & 12.30 & -0.51 & 4.87 \\
Bali-NTT & 0.47 & 11.38 & -0.31 & 3.66 \\
Molucca-Papua & 0.48 & 13.32 & 0.48 & 5.51 \\
\hline
\end{tabular}

Table 6. Categorical values for 2015

\begin{tabular}{lcccccc}
\hline \multicolumn{1}{c}{ Average values 2015 } & PC & POD & FAR & CSI & ETS & FBI \\
\hline Sumatra & 0.79 & 0.77 & 0.37 & 0.52 & 0.36 & 1.26 \\
Java & 0.84 & 0.79 & 0.38 & 0.53 & 0.42 & 1.31 \\
Kalimantan & 0.80 & 0.78 & 0.31 & 0.58 & 0.41 & 1.13 \\
Sulawesi & 0.81 & 0.67 & 0.33 & 0.49 & 0.36 & 1.07 \\
Bali-NTT & 0.86 & 0.61 & 0.33 & 0.47 & 0.38 & 0.93 \\
Molucca-Papua & 0.78 & 0.65 & 0.35 & 0.47 & 0.32 & 1.05 \\
\hline
\end{tabular}

Table 7. Statistical values for 2016

\begin{tabular}{lcccc}
\hline \multicolumn{1}{c}{ Average values 2016 } & CC & RMSE & ME & MAE \\
\hline Sumatra & 0.48 & 18.32 & 1.04 & 8.65 \\
Java & 0.44 & 17.96 & 1.22 & 8.90 \\
Kalimantan & 0.45 & 18.37 & -0.19 & 8.99 \\
Sulawesi & 0.43 & 15.69 & -0.33 & 7.10 \\
Bali-NTT & 0.36 & 13.69 & -1.12 & 5.25 \\
Molucca-Papua & 0.51 & 17.27 & 1.38 & 8.27 \\
\hline
\end{tabular}

Table 8. Categorical values for 2016

\begin{tabular}{lcccccc}
\hline \multicolumn{1}{c}{ Average values 2016 } & PC & POD & FAR & CSI & ETS & FBI \\
\hline Sumatra & 0.76 & 0.79 & 0.36 & 0.54 & 0.34 & 1.26 \\
Java & 0.75 & 0.78 & 0.38 & 0.52 & 0.32 & 1.31 \\
Kalimantan & 0.77 & 0.80 & 0.30 & 0.59 & 0.37 & 1.15 \\
Sulawesi & 0.76 & 0.70 & 0.37 & 0.49 & 0.31 & 1.16 \\
Bali-NTT & 0.80 & 0.60 & 0.35 & 0.44 & 0.31 & 0.94 \\
Molucca-Papua & 0.76 & 0.75 & 0.33 & 0.55 & 0.33 & 1.14 \\
\hline
\end{tabular}

Table 9. Statistical values for 2017

\begin{tabular}{lcccc}
\hline \multicolumn{1}{c}{ Average value 2016 } & CC & RMSE & ME & MAE \\
\hline Sumatra & 0.48 & 18.83 & 0.96 & 8.67 \\
Java & 0.46 & 15.56 & 0.74 & 8.39 \\
Kalimantan & 0.50 & 16.72 & 1.04 & 7.65 \\
Sulawesi & 0.45 & 18.11 & 0.08 & 8.18 \\
Bali-NTT & 0.50 & 12.15 & -1.40 & 8.29 \\
Molucca-Papua & 0.46 & 20.47 & 3.72 & 8.08 \\
\hline
\end{tabular}




\section{Research Method}

\subsection{Gauge-based rainfall}

Data for gauge-based rainfall analysis were obtained from the Indonesian Agency for Meteorology, Climatology, and Geophysics (hereafter called BMKG). These data were provided based on a gauge network of 152 meteorological stations (Figure 1) for daily values from March 2014 to December 2017.

\subsection{Satellite data}

The GSMaP project (Okamoto 2005; Ushio et al., 2009) is supported by the Japan Aerospace Exploration Agency (JAXA) and the Japan Science Technology Agency (JST). It incorporates both passive microwave (PMW) and infrared (IR) sensor data from satellites to map global precipitation at high temporal and spatial resolutions. In this study, GSMaPMVK + version 7.0 was evaluated for hourly precipitation estimates for a $0.1^{0}$ latitude/ longitude grid over the globe $\left(60^{\circ} \mathrm{S}\right.$ to $\left.60^{\circ} \mathrm{N}\right)$ from March 2014 to December 2017.

\subsection{Validation method}

In this study, standard validation statistics are used to validate the performance of GSMaPMVK rainfall products. Description of these statistics has been given in many references (Ebert 2007; Tan et al., 2017). Two types of statistics are used to verify satellite rainfall data: continuous verification statistics and categorical verification statistics. Continuous verification statistics measure the accuracy of a continuous variable such as rain quantity or intensity, while categorical verification statistics measure the correspondence between estimated and observed occurrences of events. The continuous verification statistics used to validate GSMaP in this study are correlation coefficients (CCs), mean error (ME), mean absolute error (MAE), and root mean square error (RMSE). The formulas for these statistics are as follows.

The categorical verification statistics used were calculated based on a contingency table (Table 2), to evaluate rainfall detection capabilities (Xu et al., 2017). We chose $1 \mathrm{~mm} /$ day as the threshold between rainfall and no rainfall in calculating the following indices: proportion correct (PC), probability of detection (POD), false alarm ratio (FAR), critical success index (CSI), equitable threat score (ETS), and frequency bias index (FBI), calculated by the following equations:

$\mathrm{PC}=(\mathrm{a}+\mathrm{d}) / \mathrm{n}$

PC values range between 0 and 1 , with a maximum value of 1 .

$\mathrm{POD}=\mathrm{a} /(\mathrm{a}+\mathrm{c})$

POD values range between 0 and 1 , with a maximum value of 1 .

$F A R=b /(a+b)$

FAR values range between 0 and 1 , with a perfect value of 0 .

$\mathrm{CSI}=\mathrm{a} /(\mathrm{a}+\mathrm{b}+\mathrm{c})$

CSI values range between 0 and 1 , with a maximum value of 1 .

ETS $=\left(a-a_{r}\right) /\left(a+b+c-a_{r}\right)$, where $a_{r}=(a+b)$ $(a+c) / n$

ETS values range between $-1 / 3$ and 1 , with a maximum value of 1 .

$\mathrm{FBI}=(\mathrm{a}+\mathrm{b}) /(\mathrm{a}+\mathrm{c})$

FBI values range between 0 and infinity, with a perfect value of 1

\section{Results and Discussion}

\subsection{Annual assessment}

Table 3 shows the statistical metrics of daily rainfall estimates from GSMaP-MVK in 2014 for six large islands. Kalimantan has the best CC value, of 0.51 , followed by Sulawesi (0.49), Molucca-Papua (0.48), Sumatra (0.47), Java (0.42), and Bali-NTT (0.35). However, overall 
the CC values show moderate correlation between satellites and gauges. Bali-NTT has the best RMSE value, of 8.83 , while Sumatera has the worst value, of 16.93 . The $\mathrm{ME}$ values range from -0.83 (Sulawesi) to 0.71 (Sumatra) and the MAE values range from 2.69 (Bali-NTT) to 7.66 (Sumatra). Table 4 shows rainfall detection ability in 2014, with PC values ranging from 0.73 (Sumatra) to 0.87 (Bali-NTT). GSMaP products provide reasonably good POD, ranging from 0.58 (Bali-NTT) to 0.81 (Kalimantan). The best FAR value is 0.32 (Kalimantan) while the worst value is 0.42 (Java). CSI values range from 0.42 (Bali-NTT) to 0.58 (Kalimantan). Generally, ETS values range between 0.26 (Molucca-Papua) to 0.35 (Kalimantan). FBI values range from 0.98 (Molucca-Papua) to 1.29 (Sumatra). Moreover, satellite rainfall is overestimated for most of the islands.

Table 5 shows the statistical metrics for daily rainfall estimates from GSMaP-MVK in 2015. Kalimantan and Sulawesi have the best CC values, of 0.51 , followed by Molucca-Papua (0.48), Java and Bali-NTT (0.47), and Sumatra (0.45). However, CC values generally show a moderate correlation between satellite and gauges. Bali-NTT has the best RMSE value of 11.38 but Java has the worst value of 15.83 . The ME values range from -0.51 (Sulawesi) to 1.20 (Java) and the MAE values range from 3.66 (Bali-NTT) to 6.66 (Sumatra). Table 6 shows the rainfall detection ability in 2015, with PC values ranging from 0.78 (Molucca-Papua) to 0.86 (Bali-NTT). GSMaP products have reasonably good POD, ranging from 0.61 (Bali-NTT) to 0.79 (Java). The best FAR value is 0.31 (Kalimantan) and the worst value is 0.38 (Java). CSI values range from 0.47 (Bali-NTT and Molucca-Papua) to 0.58 (Kalimantan). Generally, ETS values range between 0.32 (Molucca-Papua) and 0.42 (Java). FBI values range from 0.93 (Bali-NTT) to 1.31 (Java). Moreover, satellite rainfall is overestimated for most of the islands.

Table 7 shows statistical metrics of daily rainfall estimates from GSMaP-MVK in 2016. Molucca-Papua has the best CC value of 0.51 , followed by Sumatra (0.48), Kalimantan (0.45),
Java (0.44), Sulawesi (0.43), and Bali-NTT (0.36). CC values generally show moderate correlation between satellites and gauges. BaliNTT has the best RMSE value, of 13.69, while Kalimantan has the worst value, of 18.37. ME values range from -1.12 (Bali-NTT) to 1.38 (Molucca-Papua) and MAE values range from 5.25 (Bali-NTT) to 8.99 (Kalimantan). Table 8 shows rainfall detection ability for 2017, with PC values ranging from 0.75 (Java) to 0.80 (Bali-NTT). GSMaP products have reasonably good POD, ranging from 0.60 (Bali-NTT) to 0.80 (Kalimantan). The best FAR value is 0.30 (Kalimantan) and the worst value is 0.38 (Java). CSI values range from 0.44 (Bali-NTT) to 0.59 (Kalimantan). Generally, ETS values range between 0.31 (Sulawesi and Bali-NTT) and 0.37 (Kalimantan). FBI values range from 0.94 (BaliNTT) to 1.31 (Java). Satellite rainfall is generally over-estimated for most islands.

Table 9 show the statistical metrics for daily rainfall estimates from GSMaP-MVK for 2017. Kalimantan and Bali-NTT have the best CC values of 0.50 , followed by Sumatra (0.48), Molucca-Papua and Java (0.46), and Sulawesi (0.45). Overall, the CC values show moderate correlation between satellites and gauges. BaliNTT has the best RMSE value of 12.15 and Molucca-Papua has the worst value of 20.47. ME values range from -1.40 (Bali-NTT) to 3.72 (Molucca-Papua) and MAE values range from 7.65 (Kalimantan) to 8.67 (Sumatra). Table 10 shows rainfall detection ability for 2017, with PC values ranging from 0.73 (Sulawesi and Molucca-Papua) to 0.82 (Bali-NTT). GSMaP products have reasonably good POD, ranging from 0.62 (Bali-NTT) to 0.84 (Kalimantan). The best FAR value is 0.31 (Kalimantan and BaliNTT) and the worst value is 0.39 (Sulawesi and Molucca-Papua). CSI value ranges from 0.48 (Bali-NTT) to 0.61 (Kalimantan). Generally, ETS values range between 0.29 (Sulawesi) and 0.39 (Java). FBI value ranges from 0.91 (BaliNTT) to 1.58 (Molucca-Papua). Moreover, satellite rainfall is over-estimated for most of the islands. 
Table 10. Categorical values for 2017

\begin{tabular}{lcccccc}
\hline \multicolumn{1}{c}{ Average value 2017 } & PC & POD & FAR & CSI & ETS & FBI \\
\hline Sumatra & 0.76 & 0.78 & 0.34 & 0.55 & 0.34 & 1.21 \\
Java & 0.80 & 0.79 & 0.35 & 0.55 & 0.39 & 1.26 \\
Kalimantan & 0.77 & 0.84 & 0.31 & 0.61 & 0.38 & 1.22 \\
Sulawesi & 0.73 & 0.73 & 0.39 & 0.49 & 0.29 & 1.25 \\
Bali-NTT & 0.82 & 0.62 & 0.31 & 0.48 & 0.36 & 0.91 \\
Molucca-Papua & 0.73 & 0.79 & 0.39 & 0.51 & 0.30 & 1.58 \\
\hline
\end{tabular}

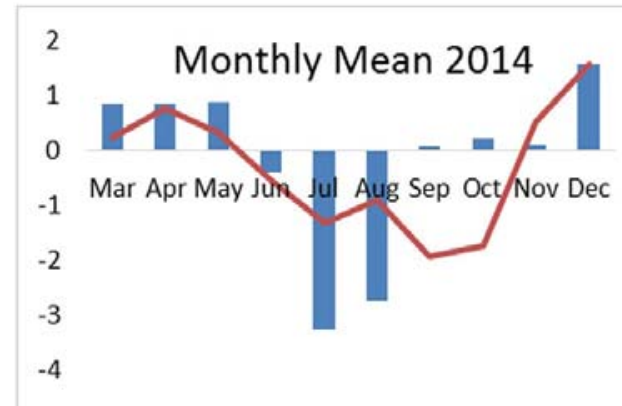

(a)

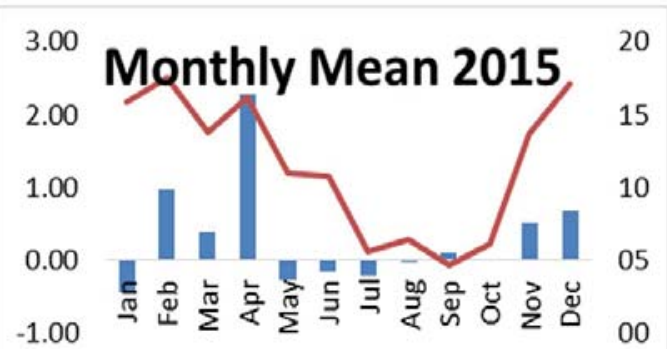

(c)

$$
\text { ME } \longrightarrow \text { RMSE }
$$

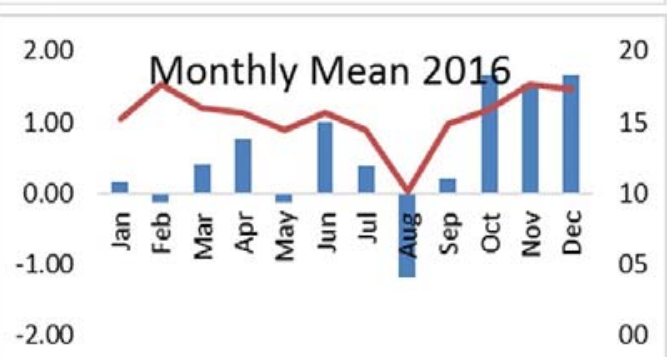

(e)

ME $\longrightarrow$ RMSE

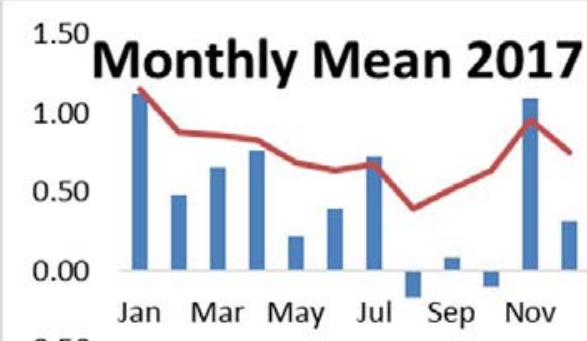
$-0.50$

(g)
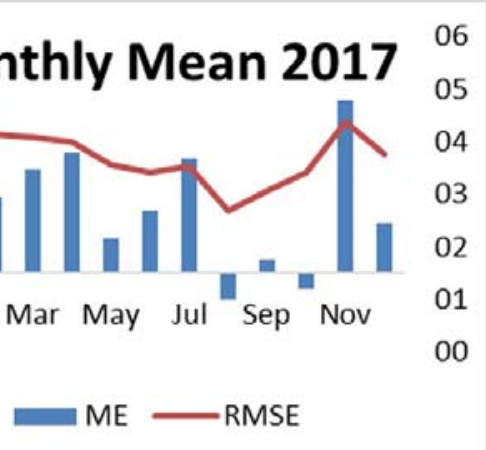

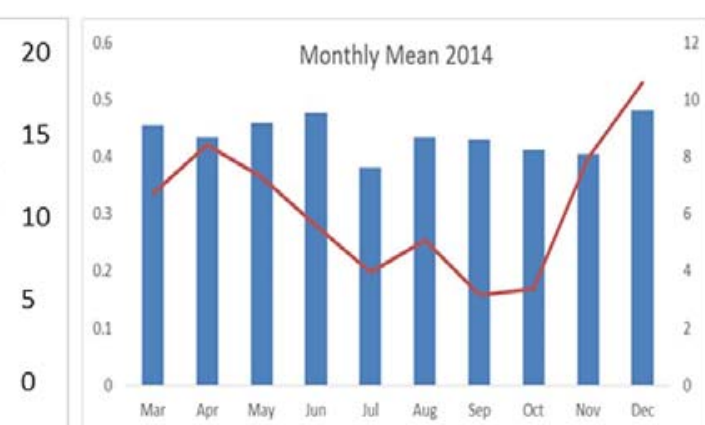

(b) $=C \mathrm{C}$ MaE

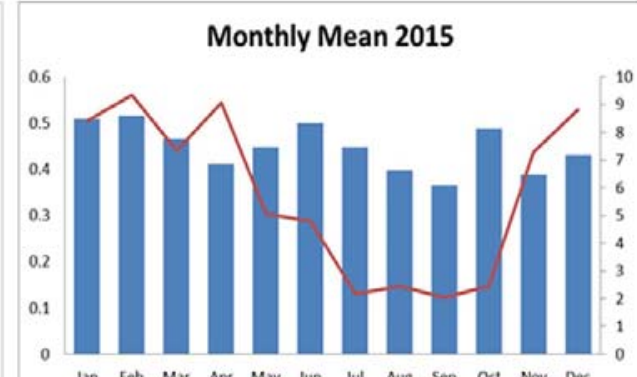

(d)

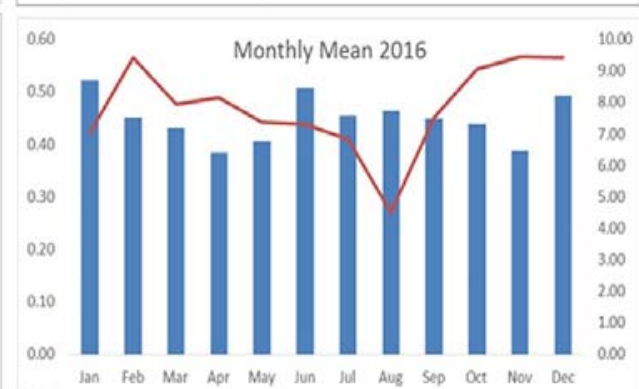

(f) $=\lll$ -

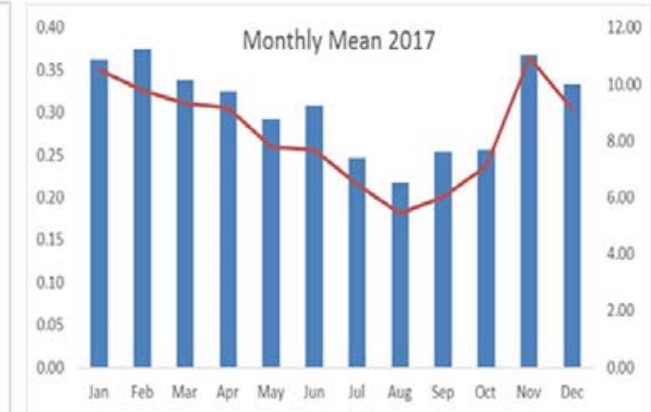

(h)

Figure. 2 Monthly means of ME and RMSE in (a) 2014 (c) 2015 (e) 2016, and (g) 2017 and of CC and MAE in (b) 2014 (d) 2015 (f) 2016 (h) 2017. 
It is apparent that daily rainfall over large islands such as Kalimantan has better CC than small island such as Bali-NTT (Tables 3, 5, and 7), and this is because the GSMaP satellites can monitor convective clouds more effectively over large islands. It is correspondingly difficult to monitor diurnal variation in convective clouds over small islands. According to statistical measurements, BaliNTT has the best RMSE, but for categorical measurements it has the lowest POD. This is because five stations had POD values of less than 0.45 , thus influencing the average value of POD. There are negative values of ME for some islands, meaning that the GSMaP rainfall forecast is under-estimated for those islands.

\subsection{Monthly assessment}

Figure 2 shows the monthly values of CC, RMSE, ME, and MAE. In 2014, the best accuracy according to RMSE is 6.91 in September and the worst is 15.10 in November. The highest ME value is 0.85 in April and is over-estimated compared to rain-gauged data, while the lowest ME is -3.26 in July, as seen in Figure 2(a). The highest value of CC is 0.48 in December while the lowest is 0.38 in July. Moreover, MAE value was highest in December at 10.58 and lowest in September at 3.14, as seen in Figure 2(b). In 2015, The best accuracy according to RMSE is 4.7 in September and the worst is 17.5 in February. The highest ME value is 0.96 in February and is over-estimated compared to rain-gauged data, while the lowest ME is -0.44 in January, as seen in Figure 2(c). The highest value of CC is 0.52 in February while the lowest is 0.36 in September. Finally, MAE value is highest in February at 9.36 and lowest in September at 2.05, as seen in Figure 2(d).

In 2016, the best accuracy according to RMSE is 10.1 in August and the worst is 17.70 in November. The highest ME value is 1.67 in December and is over-estimated compared to rain-gauged data, while the lowest ME is -1.19 in August, as seen in Figure 2 (e). The highest value of CC is 0.52 in January, while the lowest is 0.38 in April. MAE value is highest in November at 9.45 and lowest in August at 4.49, as seen in Figure 2 (f). In 2017, the best accuracy according to RMSE is 2.7 in August, and the worst is 5.0 in January. The highest ME value is 1.12 in January and is over-estimated compared to rain-gauged data, while the lowest ME is -0.17 in August, as seen in Figure $2(\mathrm{~g})$. The highest value of CC is 0.37 in February while the lowest is 0.22 in August. MAE value is highest in November, at 10.94, and lowest in August, at 5.43, as seen in Figure $2(\mathrm{~h})$.

\subsection{Discussion}

Climatic rainfall characteristics for Indonesia can be divided into three regions (Aldrian and Susanto, 2003). The first (region A) comprises southern Indonesia from South Sumatra to Timor island, southern Kalimantan, Sulawesi, and part of Papua. The second region (region B) is located in northwest Indonesia from northern Sumatra to northwestern Kalimantan. The third region (region C) comprises Molucca and northern Sulawesi. Region $C$ has the strongest relationship to the El Nino southern oscillation (ENSO) phenomenon, followed by region A. Between 2014 and 2017, Indonesian rainfall was influenced by strong El Nino events from 2015 to April 2016.

The analysis presented in this study provides a quantitative comparison between satellite-based precipitation products and gauge-based precipitation analysis datasets. The GSMaP project is a recent addition to the repository of satellite-based high-resolution precipitation estimates. To facilitate the application of GSMaP and support its improvement, it is crucial to quantify and document its error characteristics. Generally, the performance of GSMaP-MVK is better than GSMaP-NRT for Indonesia (Fatkhuroyan, 2018), and this is consistent with findings for China (Tang et al., 2016), Japan, and Korea (Kim et al., 2017), and the Tibetan Plateau (Ma et al., 2016). Many previous studies have 
also indicated that complex topography may influence the accuracy of satellite data (Dinku et al., 2008; AghaKouchak et al., 2011).

$\mathrm{CC}$ values are better in the rainy season, while RMSE has the best values in the dry season. Moreover, the highest value of PC is for Bali-NTT, the highest POD value is for Borneo, and the highest FAR value is for Borneo. The verification methods used in this study were employed to extensively evaluate remote sensing precipitation estimates for issues such as bias, POD, FAR, etc. Development of methods of validation and uncertainty analysis are of great importance (Sorooshian et al., 2011), and in recent years, several efforts to develop various methods for validation of satellite-based precipitation estimates have been devised. To track the error sources associated with the retrieval processes, Tian et al. (2009) proposed an error decomposition scheme to separate the errors into three independent components, and AghaKouchak et al. (2012) investigated systematic and random error components of several satellite precipitation products.

\section{Conclusion}

The GSMaP-MVK rainfall product was assessed for annual, monthly, and daily data for Indonesia. The analysis was carried out for six large islands and for both wet and dry seasons. Generally, GSMaP-MVK is overestimated, with mean accuracy for daily rainfall estimations of $85.47 \%$ in $2014,85.74 \%$ in $2015,82.73$ in 2016, and $82.59 \%$ in 2017 . However, some discrepancies are observed when considering different rainfall features over the various regions. The enhancement of rainfall estimates over Maritime Continent regions is valuable for future hydro-climatic studies, as small changes in rainfall patterns can have strong impacts on local water budgets.

\section{Acknowledgments}

The Authors would like to acknowledge the Japan Aerospace Exploration Agency (JAXA) for supplying GSMaP rainfall data and BMKG Indonesia for supplying raingauge data.

\section{References}

Gottschalck, J.; Meng, J.; Rodell, M.; Houser, P. (2005) Analysis of multiple rainfall products and preliminary assessment of their impact on global land data assimilation system land surface states. Journal of Hydrometeorology 6(5): 573-598.

Kidd, C; Huffman, G. (2011) Global Precipitation measurement. Meteorol. Appl. 18 ; 334-353.

Vernimmen, R. R. E. ; Hooijer, A. ; Mamenun ; Aldrian, E. ; and van Dijk, A. I. J. M. (2012) Evaluation and bias correction of satellite rainfall data for drought monitoring in Indonesia, Hydrol. Earth Syst. Sci., 16, 133-146, https:/ / doi.org/10.5194/hess-16-133-2012, 2012

Buarque, D.C.; De Paiva, R.C.D.; Clarke, R.T.; Mendes, C.A.B. (2011) A comparison of amazon rainfall characteristics derived from TRMM, CMORPH and the Brazilian national rain gauge network. J. Geophys. Res. Atmos. 2011, 116.

Chen, S.; Hong, Y.; Cao, Q.; Kirstetter, P.-E.; Gourley, J.J.; Qi, Y.; Zhang, J.; Howard, K.; Hu, J.; Wang, J. (2013) Performance evaluation of radar and satellite rainfalls for typhoon Morakot over Taiwan: Are remote-sensing products ready for gauge denial scenario of extreme events? J. Hydrol. 506, 4-13.

Huffman, George J.; Adler, Robert F.; Bolvin, David T.; Gu, Guojun; Nelkin, Eric J.; Bowman, Kenneth P.; Hong, Yang; Stocker, Erich F.; Wolff, David B. (2007) The TRMM Multi-satellite Rainfall Analysis (TMPA): Quasi-global, multiyear, combined-sensor rainfall estimates at fine scales. Journal of Hydrometeorology, vol. 8, issue 1, p. 38-55.

K. Aonashi; J. Awaka; M. Hirose; T. Kozu; T. Kubota; G. Liu; S. Shige; S., Kida; S. Seto; N. Takahashi; and Y. N. Takayabu, (2009) GSMaP passive microwave rainfall retrieval algorithm: Algorithm description and validation. J. Meteor.Soc. Japan, 87A, 119-136. 
C. Kidd; V. Levizzani; J. Turk; and R. Ferraro. (2009) Satellite precipitation measurements for water resource monitoring. Journal of the American Water Resources Association, vol. 45, no. 3, pp.567-579.

R. J. Joyce and P. Xie. (2011) Kalman filter-based CMORPH. Journal of Hydrometeorology, vol. 12, no. 6, pp. 1547-1563.

AghaKouchak, A; N. Nasrollahi; E. Habib.(2009) Accounting for Uncertainties of the TRMM Satellite Estimates. Remote Sens. 1, 606-619

T. Dinku; F. Ruiz ; S. J. Connor ; and P. Ceccato.(2010) Validation and intercomparison of satellite rainfall estimates over Colombia. Journal of Applied Meteorology and Climatology, vol. 49, no. 5, pp. 1004-1014.

M. R. P. Sapiano. (2010) An evaluation of high resolution precipitation products at low resolution. International Journal of Climatology, vol. 30, no. 9, pp. 1416-1422.

M. L. Scheel ; M. Rohrer ; C. Huggel ; D. S. Villar ; E. Silvestre ; and G. J. Huffman. (2011) Evaluation of TRMM multi-satellite precipitation analysis (TMPA) performance in the Central Andes region and its dependency on spatial and temporal resolution. Hydrology and Earth System Sciences, vol. 15, no. 8, pp. 2649- 2663.

Setiawati, M.D. and Miura, F. (2016) Evaluation of GSMaP Daily Rainfall Satellite Data for Flood Monitoring: Case Study - Kyushu Japan. Journal of Geoscience and Environment Protection, 4, 101- 117. http:/ /dx.doi.org/10.4236/gep.2016.412008

Giarno ; Muhammad Pramono Hadi ; Slamet Suprayogi ; Sigit Heru Murti. (2018) Distribution of Accuracy of TRMM Daily Rainfall in Makassar Strait. Forum Geografi. Vol 32, No.1, pp 38-52

Ushio, T. ; Sasashige, K. ; Kubota, T. ; Shige, S. ; Okamoto, K ; and Aonashi, K. (2009) A Kalman

Filter Approach to the Global Satellite Mapping of Rainfall (GSMaP) from Combined Passive Microwave and Infrared Radiometric Data. Journal of Meteorological Society of Japan, 87A, 137-151.

T. Kubota ; S. Shige ; H. Hashizume et al. (2007) Global precipitation map using satelliteborne microwave radiometers by the GSMaP project: production and validation. IEEE Transactionson Geoscience and Remote Sensing, vol. 45, no. 7, pp. 2259-2275,2007.

T.Kubota ;T.Ushio ; S. Shige ; S.Kida ; M.Kachi ; and K. Okamoto. (2009) Verification of highresolution satellite-based rainfall estimates around Japan using a gauge-calibrated groundradar dataset. 2. Global Satellite Mapping of Precipitation (GSMaP) Project," Journal of the Meteorological Society of Japan. Series II, vol. 87, pp. 203-222, 2009.

Promasakha, K; and Sakolnakhon (2013) Comparison the Estimate Rainfall from Global Satellite Mapping of Rainfall (GSMaP) to Ground-based Rainfall data over Thailand. 1st Joint Project Team Meeting for Sentinel Asia STEP3 (JPTM2013), 27-29 September 2013.

K.Okamoto ;T.Ushio;T. Iguchi ; N.Takahashi ; and K. Iwanami. (2005) The global satellitemapping of precipitation (GSMaP) project. Proceedings of the IEEE International Geoscience and Remote

Sensing Symposium (IGARSS '05), pp. 3414-3416.

E. Ebert. (2007) Methods for verifying satellite precipitation estimates. in Measuring Precipitation from Space,pp.345-356 :Springer, 2007.

Tan, M.L.; Tan, K.C.; Chua, V.P.; Chan, N.W. (2017) Evaluation of TRMM product for monitoring drought in the Kelantan River Basin, Malaysia. Water 2017, 9, 57.

Xu, R.; Tian, F.; Yang, L.; Hu, H.; Lu, H.; Hou. (2017) A. Ground validation of GPM IMERG and TRMM 3B42V7 rainfall products over southern Tibetan Plateau based on a high-density rain-gauge network. J. Geophys.Res. Atmos. 2017, 122, 910-924. 
Aldrian, E ; and Susanto, R.D. (2003). Identification of three dominant rainfall regions within indonesia and their relationship to sea surface temperature. International Journal of Climatology. Vol 23. pp.1435-1452.

Fatkhuroyan, Trinah Wati, (2018) Accuracy Assessment of Global Satellite Mapping of Precipitation (GSMaP) Product Over Indonesian Maritime Continent. The 4th International Seminar on Sciences. IOP Conf. Ser.: Earth Environ. Sci. 187 012060. doi :10.1088/17551315/187/1/012060

Tang, G.; Ma, Y.; Long, D.; Zhong, L.; Hong, Y. (2016) Evaluation of GPM day-1 IMERG and TMPA version-7 legacy products over mainland China at multiple spatiotemporal scales. J. Hydrol. 2016, 533, 152-167.

Kim, K.; Park, J.; Baik, J.; Choi, M. (2017) Evaluation of topographical and seasonal feature using GPM IMERG and TRMM 3B42 over Far-east Asia. Atmos. Res. 2017, 187, 95-105.

Ma, Y. ; G. Tang ; D. Long ; B. Yong ; L. Zhong ; W. Wan, and Y. Hong. (2016) Similarity and error intercomparison of the GPM and its predecessor-TRMM multisatellite precipitation analysis using the best available hourly gauge network over the Tibetan Plateau. Remote Sens., 8, 569, doi:https:// doi.org/10.3390/rs8070569.

T. Dinku; S. Chidzambwa; P. Ceccato ; S. J. Connor ; and C. F. Ropelewski. (2008) Validation of high-resolution satellite rainfall products over complex terrain. International Journal of Remote Sensing Vol.29, no.14, pp.4097-4110.

A. AghaKouchak ; A. Behrangi ; S. Sorooshian ; K. Hsu ; and E. Amitai. (2011) Evaluation of satellite-retrieved extreme precipitation rates across the central United States. Journal of Geophysical Research-Atmospheres, vol. 116, Article ID D02115.

Sorooshian, S.; AghaKouchak, A.; Arkin, P.; Eylander, J.; Foufoula-Georgiou, E.; Harmon, R.; Hendrickx, J.M.H.; Imam, B.; Kuligowski, R.; Skahill, B. (2011) Advancing the remote sensing of precipitation. Bull. Am. Meteorol. Soc. 2011, 92, 1271-1272.

Tian, Y.; Peters-Lidard, C.D.; Eylander, J.B.; Joyce, R.J.; Huffman, G.J.; Adler, R.F.; Hsu, K.L.;Turk, F.J.; Garcia, M.; Zeng, J. (2009) Component analysis of errors in satellite-based precipitation estimates. J. Geophys. Res.: Atmos. 114, doi:10.1029/2009JD011949.

AghaKouchak, A.; Mehran, A.; Norouzi, H.; Behrangi. (2012) A. Systematic and random error components in satellite precipitation data sets. Geophys. Res. Lett. 2012, 39, doi:10.1029/2012GL051592. 